\title{
PROTOCOL FOR PURIFICATION OF A RAT BLOOD SERUM PROTEIN FRACTION ENRICHED IN GAMMA-BUTYROBETAINE ESTERASE ACTIVITY
}

\author{
Lida Bagdonienè ${ }^{*}$ Danutè Labeikytè ${ }^{*}$, Ivars Kalviṇš ${ }^{* *}$, Benediktas Juodka*, \\ and Nikolajs Sjakste** \\ * Department of Biochemistry and Biophysics, Vilnius University, M. K. Čiurlionio 21, Vilnius, LT-2009, LITHUANIA \\ ${ }^{* *}$ Latvian Institute of Organic Synthesis, Aizkraukles 21, Rīga, LV1006, LATVIA, \\ e-mail: Nikolajs.Sjakste@lu.Iv
}

Communicated by Nikolajs Sjakste

\begin{abstract}
Although described some time ago, gamma-butyrobetaine esters and related compounds have not gained much attention from researchers, and their physiological function remains obscure. Formerly we detected GBB-esterase enzymatic activity in rat blood serum. The aim of the present work was to develop a protocol that would enable purification of the protein fraction enriched in GBB esterase activity from rat blood serum. Chromatography on DEAE Sepharose at pH 4.2 enabled to purify a protein fraction enriched in enzymatic activity, but represented by numerous polypeptides. Following separation of this fraction by means of chromatography on DEAE Sepharose at $\mathrm{pH} 6.5$ or heparin Sepharose chromatography at $\mathrm{pH} 7.0$ did not lead to significant decrease of polypeptide number. When the above fraction was further fractionated by means of DEAE Sepharose chromatography at pH 7.4 or Bio Gel P150 chromatography the enzymatic activity was lost. Combination of DEAE Sepharose at pH 4.2 and affinity chromatography with procainamide appears to be the most suitable approach.
\end{abstract}

Key words: gamma-buturobetaine esterase, gamma-butyrobetaine esters, blood serum, affinity chromatography, proacainamide.

\section{INTRODUCTION}

Although described some time ago, gamma-butyrobetaine esters and related compounds have not gained much attention from researchers. Numerous studies performed by E. Hosein and co-workers in the 1960s and 1970s indicated the multiple functions of these compounds (Hosein and Proulx, 1964; Hosein et al., 1967; 1970; 1971). It has been reported that, for example, in addition to being a carnitine precursor, gamma-butyrobetaine (GBB) can undergo esterification in mammalian brain tissue (Hosein et al., 1971). The structure of $\gamma$-butyrobetaine ethyl ester strikingly resembles that of acetylcholine. The distance between positively and negatively charged poles in both molecules is almost identical. The existence of a specific signal transfer system based on GBB esters was recently suggested (Kalvinsh et al., 2006). The possible existence of such a system is indicated by the reported increase in GBB levels in stressed animals (Thomizek et al., 1963) and the cholinergic activity of GBB esters (Hosein et al., 1970). Seeking arguments to support this hypothesis, we identified GBB-esterase enzymatic activity in rat blood serum (Orbidāne et al., 2004).

The signal transfer hypothesis can be formulated as follows: 1. A specific signal shifts the equilibrium between
GBB hydroxylation to carnitine and GBB esterification towards the GBB esters. Trace amounts of the GBB esters are physiologically active, thus, the effect should be rather fast. 2. The GBB ester binds its specific receptor; the GBB esterase, acting like acetylcholinesterase, performs hydrolysis of the ester. 3. GBB ester hydrolysis triggers the signal transduction. Secondary messengers including nitric oxide can be involved in the process. Existence of the GBB esterase cannot exclude action of the GBB esters via acetylcholine receptors, as the substance can bind them. Recent in vitro data (Dambrova et al., 2004) have shown that the GBB methyl ester is a potent agonist for $m$-type acetylcholine receptors and that GBB affinity to these receptors is much lower. A computer model of the molecular interactions between the GBB ethyl and methyl esters and the active centre of acetylcholine esterase indicates that acetylcholine and GBB ethyl ester have the same binding modes (Sjakste et al., 2005a, b; Kalvinsh et al., 2006). This suggests that hydrolysis of GBB esters by this enzyme is quite possible. Thus, characterisation of a specific enzyme performing hydrolysis of GBB esters or providing a solid background enabling to ascribe this function to acetylcholinesterase remains crucial for validation of the above hypothesis. 
Develeping a protocol for purification of the the enzyme is an important step to reach this goal. The aim of the present work was to develop a protocol for partial purification of protein fractions performing GBB esterase activity in the rat blood serum.

\section{MATERIALS AND METHODS}

Reagents. DEAE-sepharose Fast Flow and HP-sepharose Fast Flow were supplied by Amersham Biosciences, BioGel P 150 was from BioRad, USA. Polygram SIL G/UV 254 plastic sheets $(40 \times 80 \mathrm{~mm})$ from Macherey-Nagel, Germany), polyethylene glycol 20000, and 6-aminocaproic acid from Roth (Germany). Fast Blue RR salt, CNBr-activated Sepharose ${ }^{\mathrm{TM}}$ 4B -GE Healthcare Bio Sciences (Sweden), $\mathrm{S}$-acetylthiocholine iodide was obtained from Acros organics (USA).

Butyrylcholine chloride, procainamide, 1-(3-dimethylaminopropyl)-3-ethylcarbodiimide hydrochloride and 1,5- Bis(4allyldimethyl-ammoniumphenyl)-pentan-3-one dibromide (Bw 284c51) were from Sigma (Germany).

Blood serum. All manipulations with animals were performed in accordance with Lithuanian and Latvian regulations, and in agreement with EU rules; permission from the Ethics Commissions of the Ministry of Agriculture was obtained to perform this study. Blood was obtained from male Wistar rats decapitated under slight ether narcosis. Collected blood was stored at $37{ }^{\circ} \mathrm{C}$ for $2 \mathrm{~h}$ and then centrifuged $20 \mathrm{~min}$ at $5000 \mathrm{~g}$ to obtain serum in the supernatant. Serum was stored at $4{ }^{\circ} \mathrm{C}$ until used (up to 3-10 days).

GBB-O-NF esterase activity was measured on a Perkin Elmer Lambda-20 spectrophotometer using GBB-Onaphthol (GBB-O-NF) as substrate essentially as described in (Morgan et al., 1994). Briefly, the hydrolysis of GBB-ONF to 1-naphthol was estimated by the increase in absorbance at $322 \mathrm{~nm}$ (the extinction coefficient for 1 -naphthol is $2.2 \mathrm{mM}^{-1} \mathrm{~cm}^{-1}$ ). The reactions were conducted in a 1-ml cuvette and initiated by the addition of substrate $(10 \mu \mathrm{l}$ of $100 \mathrm{mM}$ stock in water). Initial velocities were measured at $25{ }^{\circ} \mathrm{C}$ for $10 \mathrm{~min}$ in one $\mathrm{mL}$ of assay mixture composed of $100 \mathrm{mM}$ sodium phosphate buffer, $\mathrm{pH}$ 7.4; $0.1 \mathrm{mM} \mathrm{GBB-O-NF}$ and serum or fractionated enzyme preparation. In the measurements, the spontaneous hydrolysis of GBB-O-NF and the effects of additives on substrate hydrolysis were eliminated by using different blank tubes containing appropriate combinations of compounds. A unit of GBB-O-NF esterase was defined as the amount of enzyme which catalyzes the formation of $1 \mu$ mole product per min under these conditions.

Dialysis of rat serum. $10 \mathrm{ml}$ of serum was dialyzed against $0.02 \mathrm{M} \mathrm{Na}$ acetate buffer, $1 \mathrm{mM}$ EDTA, $\mathrm{pH} 4.5$ for 12 hours and 3 hours against $0.02 \mathrm{M} \mathrm{Na}$ acetate containing $1 \mathrm{mM}$ EDTA, $\mathrm{pH} 4.2$.

Salting-out was performed by $40-60 \%$ saturation of $\left(\mathrm{NH}_{4}\right)_{2} \mathrm{SO}_{4}$.
DEAE Sepharose chromatography pH 4.2. $10 \mathrm{ml}$ of dialyzed serum (700 mg total protein) was applied to a DEAE Sepharose column $(0.8 \mathrm{~cm} \times 14 \mathrm{~cm})$, eluted with $25 \mathrm{ml} 0.02$ $\mathrm{M} \mathrm{Na}$ acetate buffer $\mathrm{pH} 4.2$, then with a 70/70 ml gradient of $0-0.15 \mathrm{M} \mathrm{NaCl}$ in $0.02 \mathrm{M} \mathrm{Na}$ acetate buffer $\mathrm{pH} 4.2$ containing $1 \mathrm{mM}$ EDTA. Flow rate was $0.3 \mathrm{ml} / \mathrm{min}$. Concentration of fractions was performed with Polyethylenglycol 20000 .

DEAE Sepharose chromatography at pH 6.5. A $2.4 \mathrm{ml}$ solution containing $10.5 \mathrm{mg}$ of proteins was obtained after DEAE sepharose chromatography at $\mathrm{pH} 4.2$ (peak II manifesting enzymatic activity) was dialised against $0.02 \mathrm{M}$ phosphate buffer $\mathrm{pH} 6.5,1 \mathrm{mM}$ EDTA and after dialysis applied onto another column $(0.8 \mathrm{~cm} \times 7 \mathrm{~cm})$ with DEAE sepharose $\mathrm{pH} 6.5,1 \mathrm{mM}$ EDTA. A 40/40ml gradient of $0-0.15 \mathrm{M} \mathrm{NaCl}$ in phosphate buffer $\mathrm{pH} 6.5,1 \mathrm{mM}$ EDTA was used for fractionation. The flow rate was $0.3 \mathrm{ml} / \mathrm{min}$.

DEAE Sepharose chromatography at pH 7.4. A $2.4 \mathrm{ml}$ solution containing $10.5 \mathrm{mg}$ of proteins obtained after DEAE sepharose chromatography at $\mathrm{pH} 4.2$ (peak II manifesting enzymatic activity) was dialised against $0.02 \mathrm{M}$ Tris $\mathrm{HCl}$ buffer $\mathrm{pH} 7.4$ and after dialysis was applied onto another column $(0.8 \mathrm{~cm} \times 7 \mathrm{~cm})$ with DEAE sepharose $\mathrm{pH}$ 7.4. A $40 / 40 \mathrm{ml}$ gradient $0.1-0.5 \mathrm{M} \mathrm{NaCl}$ in $0.02 \mathrm{M}$ Tris $\mathrm{HCl}$ buffer $\mathrm{pH} 7.4$ with $1 \mathrm{mM}$ EDTA was used. Flow rate was $0.3 \mathrm{ml} / \mathrm{min}$

Heparin Sepharose chromatography at pH 7. A $4 \mathrm{ml}$ solution containing $10.5 \mathrm{mg}$ of proteins obtained after DEAE sepharose chromatography at $\mathrm{pH} 4.2$ (peak II manifesting enzymatic activity), was dialised against $0.02 \mathrm{M}$ Tris $\mathrm{HCl}$ buffer $\mathrm{pH} 7$ with $1 \mathrm{mM}$ EDTA, concentrated with Polyethylenglycol $200001 \mathrm{~h} 4{ }^{\circ} \mathrm{C}$ and $1 \mathrm{ml}$ (10.5 mg of proteins) applied on to heparin sepharose column (size $0.8 \mathrm{~cm} \times 7$ $\mathrm{cm}$ ). A $40 / 40 \mathrm{ml}$ gradient $0-0.5 \mathrm{M} \mathrm{NaCl}$ in $0.02 \mathrm{M}$ Tris $\mathrm{HCl}$ buffer $\mathrm{pH} 7$ with $1 \mathrm{mM}$ EDTA was applied. The flow rate was $0.3 \mathrm{ml} / \mathrm{min}$

Bio Gel P150 chromatography. A $4 \mathrm{ml}$ solution containing $10.5 \mathrm{mg}$ of proteins obtained after DEAE sepharose chromatography at $\mathrm{pH} 4.2$ (peak II manifesting enzymatic activity), was dialysed against $0.05 \mathrm{M}$ Tris $\mathrm{HCl}$ buffer $\mathrm{pH} 7$ and after dialysis $4 \mathrm{ml}$ was applied on to $(0.8 \mathrm{~cm} \times 14 \mathrm{~cm})$ column with Biogel P150. The column was washed with 50 $\mathrm{mM}$ Tris $\mathrm{HCl}, \mathrm{pH} 7,1 \mathrm{mM}$ EDTA. The flow rate was 0.3 $\mathrm{ml} / \mathrm{min}$

Procainamide-Sepharose 4B chromatography. Procainamide gel was synthesised according to the method of Cuatrecasas (1970). Briefly, CNBr-activated Sepharose 4B (3g) swelled in water and washed with $20 \times 3 \mathrm{ml}$ of $1 \mathrm{mM}$ $\mathrm{HCl}$, then with $20 \times 3 \mathrm{ml}$ of water; was then coupled with 6-aminohexanoic acid $(0.26 \mathrm{~g})$ in $0.2 \mathrm{M} \mathrm{Na}_{2} \mathrm{CO}_{3} / \mathrm{NaHCO}_{3}$, $\mathrm{pH} 8.3$ buffer containing $0.5 \mathrm{M} \mathrm{NaCl}$. Excess ligand was removed by washing and the remaining active groups were blocked with $0.1 \mathrm{M}$ Tris- $\mathrm{HCl}$ buffer, $\mathrm{pH}$ 8.0. Procainamide $(0.275 \mathrm{~g} ; 100 / \mu \mathrm{mol} / \mathrm{ml}$ of gel) was coupled to the $10 \mathrm{ml}$ of 6 -aminohexanoic Sepharose 4B by addition of $10 \mathrm{ml}$ of 
0.2 M 1-(3-dimethylamino-propyl)-3-ethylcarbodiimide hydrochloride $(0.38 \mathrm{~g})$ maintaining the $\mathrm{pH}$ at 4.5 with 1 $\mathrm{MHC} 1$ for $2 \mathrm{~h}$ and then stirring at room temperature (20-25 ${ }^{\circ} \mathrm{C}$ ) for $24 \mathrm{~h}$. The gel was washed three times with $20 \mathrm{ml}$ of water. The concentration of the procainamide bound to the gel was determined by measuring the absorbance of the washings $\left(\varepsilon=16150 \mathrm{M}^{-1} \mathrm{~cm}^{-1}\right.$ at $\left.278 \mathrm{~nm}\right)$. The difference between the starting amount and the amount in the washings gave the gel-bound concentration $-0.3 \mathrm{mmol}$ procainamide was bound to $10 \mathrm{ml}$ of hexanoic-sepharose. The affinity column $(0.8 \mathrm{~cm} \times 5 \mathrm{~cm})$ was equilibrated with $20 \mathrm{mM}$ potassium phosphate, $1 \mathrm{mM}$ EDTA $\mathrm{pH} 7$ and washed with $20 \mathrm{ml}$ of $20 \mathrm{mM}$ potassium phosphate, $1 \mathrm{mM}$ EDTA pH 7.0. The column was then eluted with $38 \mathrm{ml}$ of $0.2 \mathrm{M} \mathrm{NaCl}$ in buffer. Finally, the proteins more tightly bound to procainamide were eluted with $40 \mathrm{ml}$ of $1 \mathrm{M} \mathrm{NaCl}$ in $20 \mathrm{mM}$ potassium phosphate, 1mM EDTA pH 7.0. Concentration of fractions was performed with Polyethylenglycol 20000.

Thin layer (TLC) chromatography. Polygram SIL $\mathrm{G} / \mathrm{UV}_{254}$ plastic sheets $(40 \times 80 \mathrm{~mm})$ were used for TLC chromatography. System for chromatography was n-butanol saturated with water.

Activity assay by TLC. A5 $\mu$ l solution of substrate $\left(10^{-2}\right.$ M), $10 \mu \mathrm{l} 100 \mathrm{mM}$ phosphate buffer $\mathrm{pH} 7.4,10 \mu \mathrm{l}$ enzyme fraction were incubated for 1 or 12 hours and when $8 \mu \mathrm{l}$ were applied on TLC plate. Naphtyl compounds are visualized under UV light.

SDS gel electrophoresis. $10 \%$ gels were run at 120 volt constant voltage for four hours (Laemmli, 1970). Gels were stained with Coomassie dye.

Nondenaturing gel electrophoresis. Fractions containing $30 \mu \mathrm{g}$ total protein per lane were subjected to electrophoresis in a $3 \%$ acrylamide stacking gel and a $7.5 \%$ acrylamide separating gel and run at 120 volts constant voltage for 4 hours. After electrophoresis, the gels were washed for 15 min in $100 \mathrm{mM}$ sodium phosphate buffer (pH6.8), followed by staining procedures as described below.

Staining in gels. Gels were stained for GBB-esterase and for cholinesterase activity. The unstained SDS-PAGE gel sections were washed for $15 \mathrm{~min}$ in $100 \mathrm{mM}$ sodium phosphate buffer ( $\mathrm{pH}$ 6.8) containing $25 \%$ isopropanol, and then for an additional $15 \mathrm{~min}$ in the same buffer without isopropanol. The gel sections were then incubated in the same buffer containing GBB-O-NF $(0.01 \%)$ and 4-benzolamino2,5-dimethoxybenzenediazonium chloride hemi (zinc chloride) salt, usually termed Fast Blue RR $(0.01 \%)$. Staining is based on the formation of an insoluble complex between 1-naphthol hydrolyzed from GBB-O-NF and Fast Blue RR (Yan et al., 1995). Cholinesterase staining was carried out according to Karnovsky and Roots, essentially as described by Seidman et al., 1995. Briefly, gel sections were rinsed three times with water and then in $65 \mathrm{mM}$ sodium acetate, $\mathrm{pH}$ 6.0. Afterwards they were incubated overnight in buffer containing $65 \mathrm{mM}$ sodium acetate $\mathrm{pH} \quad 6.0 \quad 0.5 \mathrm{mg} / \mathrm{ml}$ acetylthiocholine, sodium citrate $5 \mathrm{mM}$, cupric sulfate 3 $\mathrm{mM}$, and potassium ferricyanide $0.5 \mathrm{mM}$. The reactions were stopped by washing the gels with water.

Determination of protein concentrations. Protein contents in the chromatography steps during the purification procedure were estimated by measuring the absorbance at 280 $\mathrm{nm}$. In the pooled samples, the protein concentrations were determined by the method of (Bradford, 1976) using BSA as a standard.

\section{RESULTS}

Applicability of the gamma-butyrobetaine naphtyl ester assay for detection of the GBB esterase activity will be described elsewhere (Bagdoniene et al., 2009). The following protocols of the enzyme purification were tested for applicability.

Salting out with $\left(\mathbf{N H}_{4}\right)_{2} \mathbf{S O}_{4}$. It was shown that GBB-O$\mathrm{NF}$ esterase activity was preserved after salting out by $40-60 \%$ saturation of $\left(\mathrm{NH}_{4}\right)_{2} \mathrm{SO}_{4}$. However, the salting-out procedure was omitted in most of experiments as some GBB-esterase activity was lost during the salting-out step.

Fractionation on DEAE sepharose at pH 4.2. After fractionation on DEAE Sepharose at $\mathrm{pH} 4.2$ the GBB-esterase activity was identified in a peak eluted by $0.076 \mathrm{M} \mathrm{NaCl}$ (peak II, Fig. 1). Electrophoretic separation of the polypeptides of the above fraction revealed a very heterogenous composition, a polypeptide of about $70 \mathrm{kDa}$ manifested both esterase and GBB-esterase activities (Fig. 2). The same pooled fractions were subjected for nondenaturing gel electrophoresis and gels were stained for esterase with naphthyl acetate as substrate and GBB-O-NF esterase activity. Results are shown in Fig. 3. Despite diverse protein composition, the activity was detectable in a sole band. When the active fraction obtained in the previous procedure was applied on the DEAE Sepharose at $\mathrm{pH} 6.5$ and eluted with a $0-0.5 \mathrm{M} \mathrm{NaCl}$ gradient, activity was detected in the peak eluted at $0.315 \mathrm{M}$ (peak I, Fig. 4). Protein composition of the fraction still appeared to be diverse (Fig. 5). The same

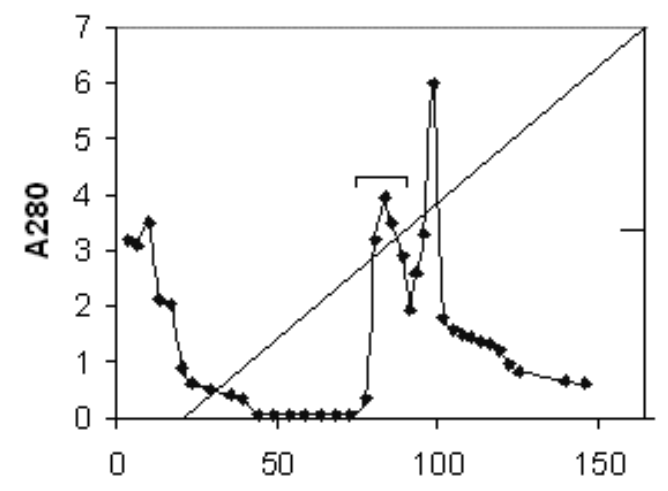

Fig. 1. Fractionation on DEAE Sepharose column at $\mathrm{pH}$ 4.2. Elution of active fraction of enzyme was achieved with $0.07 \mathrm{M} \mathrm{NaCl}$ in $25 \mathrm{ml} 0.02 \mathrm{M}$ $\mathrm{Na}$ acetate buffer $\mathrm{pH}$ 4.2. Bracket indicates pooled active fractions used for further purification. 


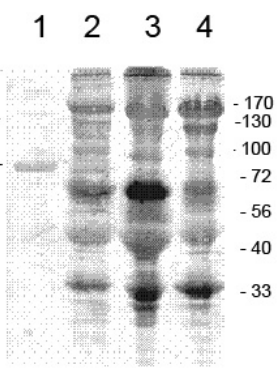

A

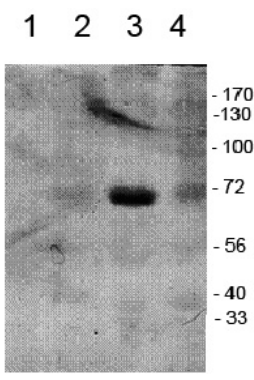

B

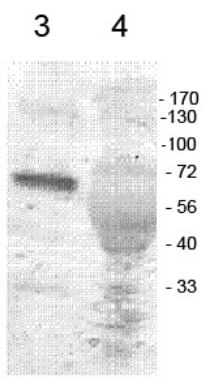

C
Fig. 2. $10 \%$ SDS-PAGE of proteins of the active fraction obtained after DEAE chromatography at $\mathrm{pH} 4.2$ stained with Coomassie dye (A), for esterase activity (B) and for GBB-esterase activity (C). 1 - butyrylcholine esterase; 2,3 - enzymatically active fractions from DEAE sepharose fractionation (peak II); 4 - unfractionated rat serum.
123456

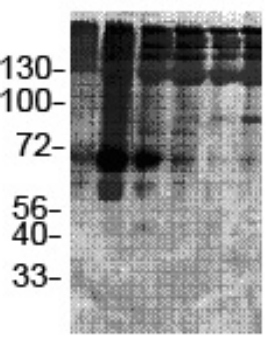

A
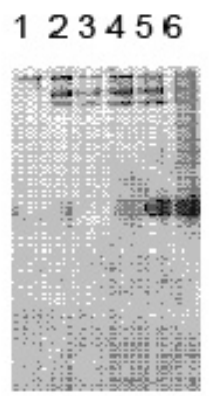

B
123456

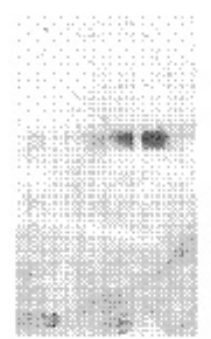

C
Fig. 3. Electrophoretic separation of proteins fractionated by means of DEAE sepharose chromatography at $\mathrm{pH} 4.2$ (peak II) in $10 \%$ polyacrilamide gel, native conditions, stained with Coomassie dye (A), for esterase activity (B) and for GBB-esterase activity (C). 1-6 - fractions of the peak II.

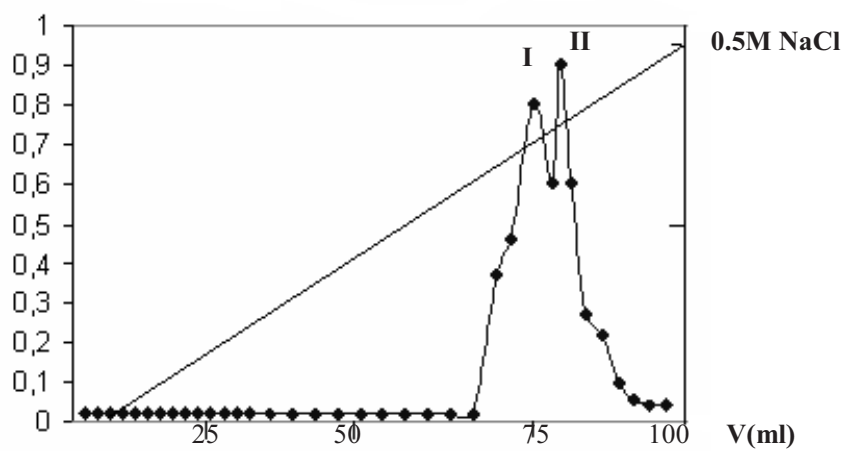

Fig. 4. Further fractionation of the proteins of peak II obtained after DEAE Sepharose chromatography at $\mathrm{pH} 4.2$ on DEAE Sepahrose at $\mathrm{pH} 6.5$.

procedure conducted at $\mathrm{pH} 7.4$ led to complete loss of the enzymatic activity (not shown). Similar loss of activity occurred also after separation of the active fraction obtained after fractionation on DEAE Sepharose at $\mathrm{pH} 4.2$ on Biogel P150 (not shown). When the activity-containing fraction obtained after fractionation on DEAE Sepharose at $\mathrm{pH} 4.2$ was dialysed, concentrated and applied to a heparin Sepharose column at $\mathrm{pH} 7$, proteins were eluted by $0-0.5 \mathrm{M} \mathrm{NaCl}$

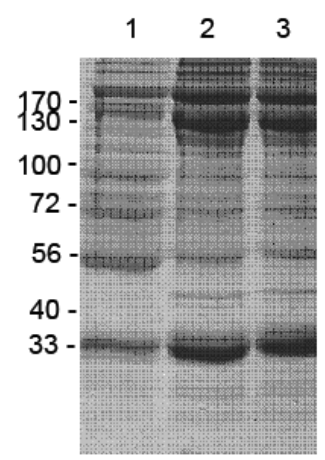

A

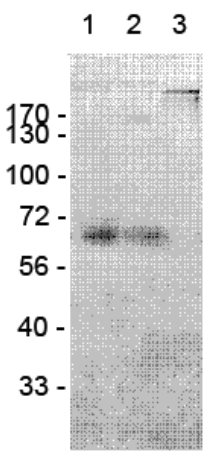

B

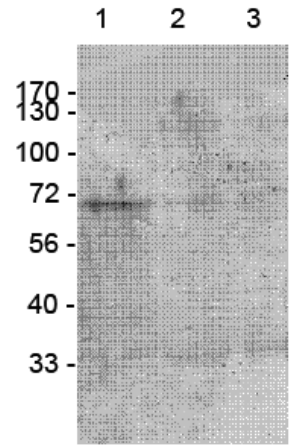

C
Fig. 5. $10 \%$ SDS-PAGE of proteins of the peak I (1 and 2) and peak 2 (3) obtained after chromatography on DEAE Sepahrose at $\mathrm{pH} 6.5$ of the active fraction separated on DEAE chromatography at $\mathrm{pH} 4.2$ and stained with Coomassie dye (A), for esterase activity (B) and for GBB-esterase activity (C).

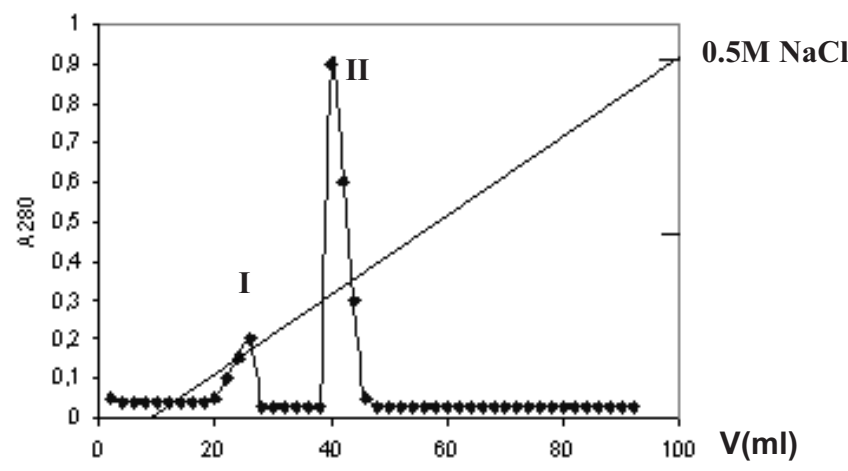

Fig. 6. Further fractionation of the proteins of peak II obtained after DEAE Sepharose chromatography at $\mathrm{pH} 4.2$ on heparin Sepharose at $\mathrm{pH} 7$.

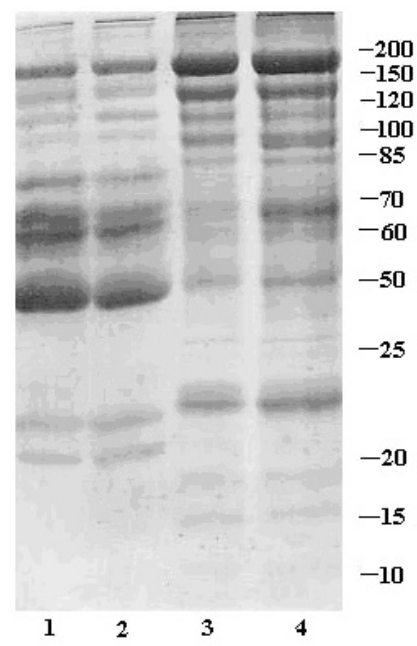

Fig. 7. $10 \%$ SDS-PAGE of proteins of the peak I ( 1 and 2$)$ and peak 2 (3 and 4) obtained after chromatography on heparin Sepharose at $\mathrm{pH} 7$ of the active fraction separated on DEAE chromatography at $\mathrm{pH} 4.2$ and stained with Coomassie dye.

gradient. Enzyme activity was detected in a peak eluted with $0.125 \mathrm{M} \mathrm{NaCl}$ (peak I, Fig. 6). In this case nine protein bands were detected by Coomassie staining (Fig. 7). Only five bands were observed after separation of this fraction in native conditions. (Fig. 8A). Staining with naphthyl acetate and staining with GBB naftyl ester revealed individual bands possessing enzyme activity (Fig. 8, B and C). GBB esterase activity in the fractions was confirmed also by 


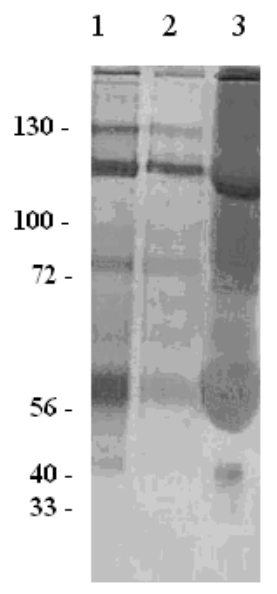

A

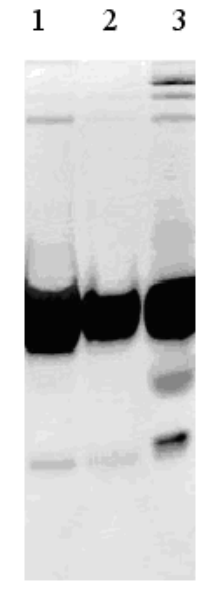

B

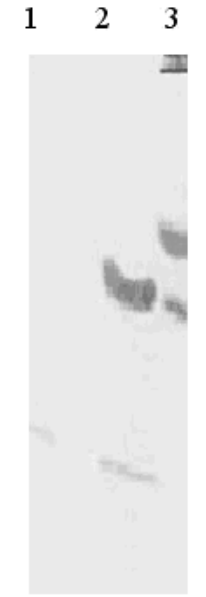

$\mathrm{C}$

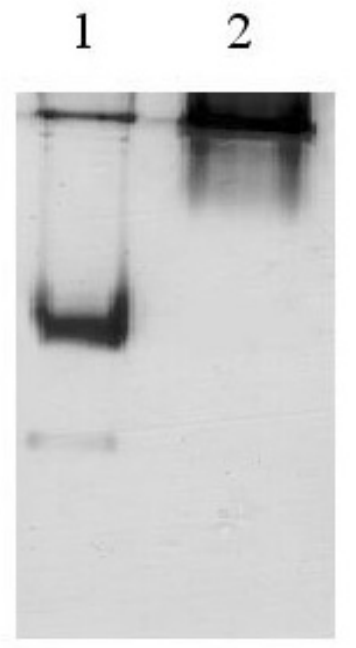

Fig. 10. Electrophoretic separation of proteins of the fraction manifesting GBB-esterase activity obtained by means of DEAE chromatography at $\mathrm{pH}$ 4.2 (1) and purified butyrylcholine esterase (2) in $7.5 \%$ polyacrilamide gel, native conditions, stained for GBBesterase activity.
Fig. 8. Electrophoretic separation of proteins obtained by means of heparin DEAE sepharose chromatography at $\mathrm{pH} 7.4$ (peak I) of the active fraction separated on DEAE chromatography at $\mathrm{pH} 4.2$ in $7 \%$ polyacrilamide gel, native conditions, stained with Coomassie dye (A), for esterase activity (B) and for GBB-esterase activity (C). 1 and 2 - fractions of the peak I, 3 unfractionated serum.
A

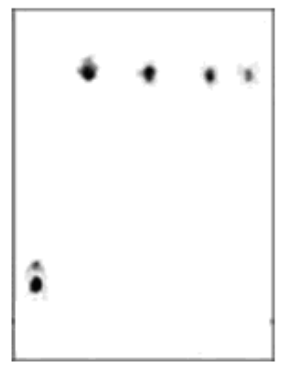

$\begin{array}{lllll}\mathrm{K} & 1 & 2 & 3 & 4\end{array}$
$\mathrm{B}$

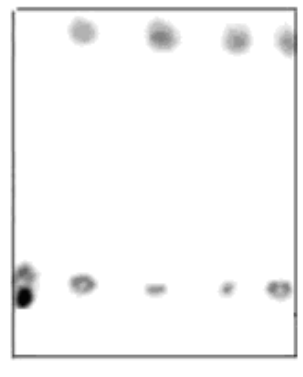

$\begin{array}{lllll}\mathrm{K} & 1 & 2 & 3 & 4\end{array}$
Fig. 9. Analysis of the gamma- butyrobetaine naphtyl ester hydrolysis by thin layer chromatography on silica gel. A: K - Gamma-butyrbetaine naphtyl ester; 1 - 4 - DEAE sepharose pH 4.2 chromatography (peak II) fractions incubated with gamma butyrobetaine naphtyl ester for 1 hour; B $\mathrm{K}$ - Gamma-butyrobetaine naphtyl ester; 1,2 - fractions obtained after DEAE sepharose chromatography at $\mathrm{pH} 6.5$ (1 and 2) of the preparation described in A incubated with gama butyrbetaine naphtyl ester for 1 hour; 3 and 4 - fractions obtained after heparine Sepharose chromatography at $\mathrm{pH} 7$ (1 and 2) of the preparation described in A with gamma butyrobetaine naphtyl ester for 1 hour.

thin-layer chromatography (Fig. 9). It seemed interesting to clarify whether hydrolysis of the GBB esters in serum was performed by butyryl choline esterase. Comparison of electrophoretic mobility in native gels of the proteins manifesting GBB-esterase activity with mobility of purified butyrylcholine esterase clearly indicated that these are different proteins (Fig. 10). As seen in Fig. 2, GBB esterase activity possesses a major polypeptide of $70 \mathrm{kDa}$ and minor peptides of 150 and $35 \mathrm{kDa}$.

Fractionation on DEAE Sepharose at $\mathrm{pH} 4.2$ with following procainamide Sepharose 4B chromatography. The above purification procedures did not seem to be sufficiently efficient, so we attempted fractionation on DEAE
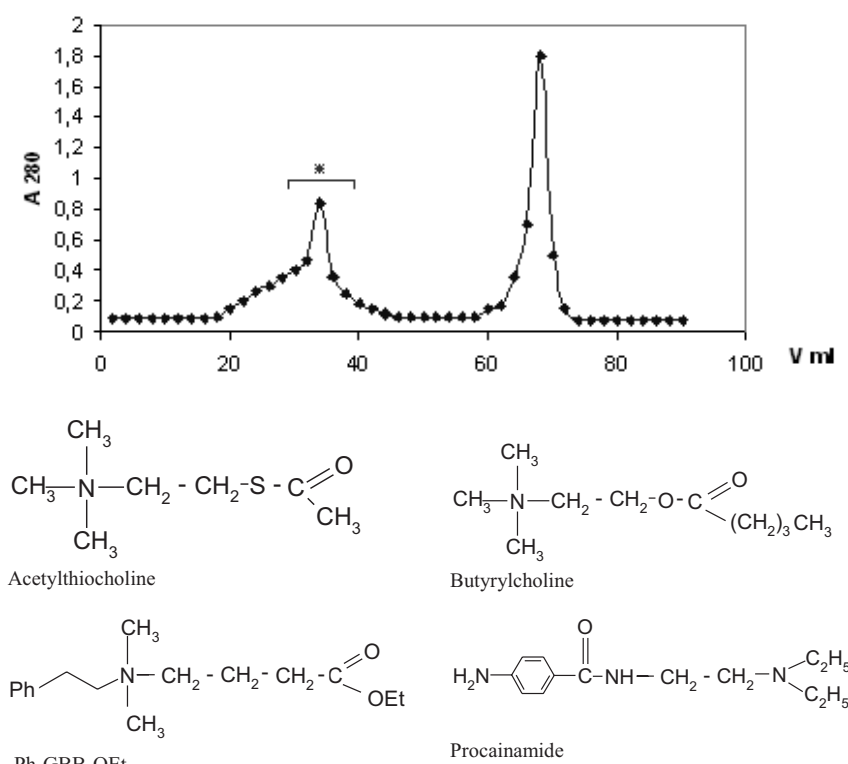

Fig. 11. Fractionation on the procainamide Sepharose column at $\mathrm{pH}$ 7.0. The GBB-O-NF esterase active fractions were eluted with $0.2 \mathrm{M} \mathrm{NaCl}$ in buffer. Fractions marked by a bracket were pooled. The remaining proteins were eluted with $1 \mathrm{M} \mathrm{NaCl}$.

Sepharose at pH 4.2 with subsequent procainamide Sepharose 4B chromatography (Lockridge et al., 2005). Serum was dialysed against acetate buffer $\mathrm{pH}$ 4.2. The dialysate was fractionated by ionic exchange chromatography on DEAE Sepharose at $\mathrm{pH}$ 4.2. Fractions manifesting GBB esterase activity (Fig. 1) were pooled and subjected to chromatography on a procainamide column. Procainamide is ligand specific for the choline binding site (see insertion in Fig. 11). Procainamide affinity chromatography was found to be efficient for purification of most cholinesterases (Lockridge et al., 2005). We suppose that procainamide affinity chromatography will also operate for GBB esterase purification. GBB-O-NF and choline esters are structurally relative to procainamide. The GBB-esterase activity containing proteins were eluted with $0.2 \mathrm{M} \mathrm{NaCl}$. The proteins bound more tightly to procainamide were eluted with $1 \mathrm{M}$ 


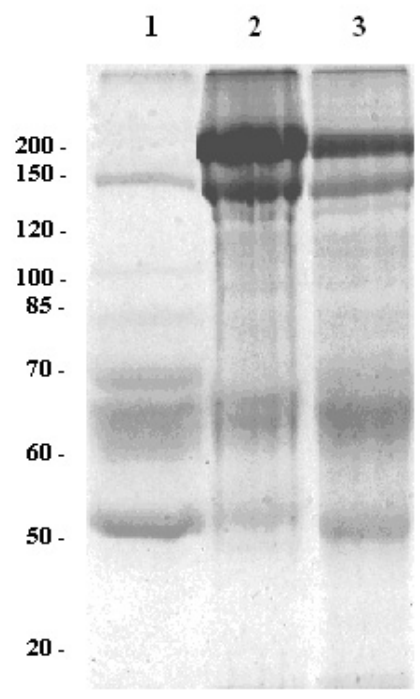

Fig. 12. 12\% SDS-PAGE stained with Coomassie dye. 1-active fraction eluted with $0.2 \mathrm{M} \mathrm{NaCl}$ from procainamide gel; 2 - fraction eluted from procainamide gel with $1 \mathrm{M} \mathrm{NaCl} 3$ - active fraction after DEAE chromatography $\mathrm{pH} 4.2$.

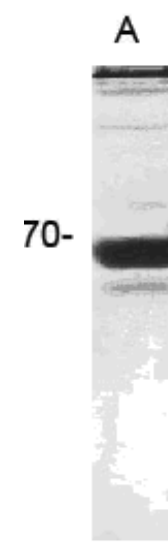

B

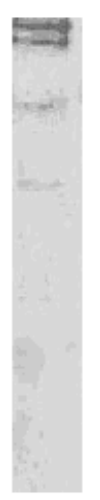

C

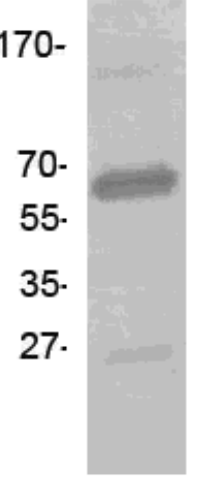

D

$170-$

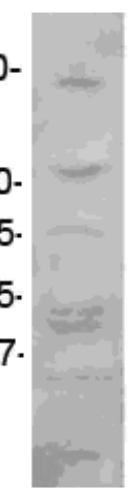

Fig. 13. A - 7.5\% Native PAGE of the fraction eluted with $0.2 \mathrm{M} \mathrm{NaCl}$ from procainamide gel stained for GBB-O-NF esterase activity; B - $7.5 \%$ Native PAGE of the fraction eluted with $0.2 \mathrm{M} \mathrm{NaCl}$ from procainamide gel stained for choline esterase activity. C - 10\% SDS PAGE of fraction eluted with $0.2 \mathrm{M} \mathrm{NaCl}$ from procainamide gel stained for GBB-O-NF esterase activity; D - 10\% SDS PAGE of fraction eluted with $0.2 \mathrm{M} \mathrm{NaCl}$ from procainamide gel stained for choline esterase activity.

$\mathrm{NaCl}$ (Fig. 11). Comparison of enzymatic activity and protein content in the fraction indicated that we have achieved a 68-fold increase in specific activity of the GBB-esterase. The active fraction in SDS-gels was represented by several polypeptides (Fig. 12). Staining native gels of the active fraction for GBB-esterase activity revealed several bands, different from those manifesting choline esterase activity (Fig.13, A, B). One of them contained about $95 \%$ of the total GBB-esterase activity. Four distinct bands of 160, 70, 56 and $35 \mathrm{kDa}$ were seen on SDS-PAGE gels stained for GBB-esterase activity. The $70 \mathrm{kDa}$ band contained about $95 \%$ of the total activity, again, the bands did not colocalise with polypeptides manifesting choline esterase activity (Fig. 13, C, D).

\section{DISCUSSION}

Combination of DEAE Sepharose at pH 4.2 and affinity chromatography with procainamide enabled us to obtain a protein fraction 68 times enriched in the GBB-esterase enzymatic activity. Our results clearly indicate advantages of affinity chromatography from the point of view of purification efficiency. Purification and characterisation of the gamma-butyrobetaine esterase is presently on line. Utility of procainamide for purification of the GBB-esterase activity raises again a question about existence of the specific GBB-esterase, as procainamide is an acetylcholine analogue. Despite still rather diverse composition of our fractions and presence of the acetylcholineserases therein, we could discriminate peptide bands possessing either acetylcholinesterase or GBB-esterase activities. These results indicate a potential for further characterisation of GBBesterases of rat blood serum by means of two-dimensional gel electrophoresis followed by mass-spectrometry.

The hydrolysis of GBB-esters by some enzyme in blood serum indicates the physiological significance of these substances. The possible physiological function of such an enzyme also arises. The GBB-ester-dependent signal transfer described in the raised hypothesis is quite possible in brain or other tissues; however, it hardly takes place in blood serum. In our opinion, the blood serum GBB-esterase together with blood acetylcholine esterase, butyrylcholinesterase, carboxylesterase and paraoxonase is involved in detoxification of hazardous substances, (Nigg and Knaak, 2000; Wheelock et al., 2008). Probably, the enzyme can protect the organism against excessive molecules of gammabutyrobetaine esters synthesized in other organs for functional purposes. Substances manifest strong cholinergic activity (Абдикалиев и др., 1991; Меерсон и др., 1991a, 1991b), excess of gamma-butyrobetaine esters could be dangerous, therefore, GBB-esters are constantly hydrolysed by the blood serum GBB-esterase.

The conclusions are the following:

1. Combination of DEAE Sepharose at pH 4.2 and affinity chromatography with procainamide enables to obtain a protein fraction 68-times enrichment compared to unfractionated serum in the GBB-esterase enzymatic activity.

2. Peptide composition of the fraction is still diverse, but suitable for further analysis.

3. GBB-esterase and acetylcholinesterase activities are performed by different peptides of the fraction.

\section{ACKNOWLEDGEMENTS}

This work was supported by a Taiwanese-Latvian-Lithuanian project „, Purification and characterisation of the gamma-butyrobetaine esterase”.

\section{REFERENCES}

Bagdoniene, L., Labeikyte, D., Kalviņs, I., Borutinskaite, V., Prokofjevs, A., Trapencieris, P., Juodka, B., Sjakste, N. (2009). Rat serum carboxylesterase partly hydrolyses gamma-butyrobetaine esters. Arh. Hig. Rada Toksikol., 60, 147-156. 
Bradford, M.M. (1976). A rapid and sensitive method for the quantitation of microgram quantities of protein utilizing the principle of protein-dye binding. Anal. Biochem., 72, 248-254.

Connelly, P.W., Maguire, G.F., Draganov, D.I. (2004). Separation and quantitative recovery of mouse serum arylesterase and carboxylesterase activity. J. Lipid Res., 45, 561-566.

Cuatrecasas, P. (1970). Protein purification by affinity chromatography: Derivatizations of agarose and polyacrylamide beads. J. Biol. Chem., 245, 3059-3065.

Dambrova, M., Chlopicki, S., Liepinsh, E., Kirjanova, O., Gorshkova, O., Kozlovski, V.I., Uhlen, S., Liepina, I., Petrovska, R., Kalvinsh, I. (2004). The methylester of gamma-butyrobetaine, but not gamma-butyrobetaine itself, induces muscarinic receptor-dependent vasodilatation. Naunyn Schmiedebergs Arch. Pharmacol., 369, 533-539.

Hosein, E.A., Booth, S.J., Gasoi, I., Kato, G. (1967). Neuromuscular blocking activity and other pharmacologic properties of various carnitine derivatives. J. Pharmacol. Exp. Ther., 156, 565-572.

Hosein, E.A., Kato, A., Vine, E., Hill, A.M. (1970). The identification of acetyl-L-carnitylcholine in rat brain extracts and the comparison of its cholinomimetic properties with acetylcholine. Can. J. Physiol Pharmacol., 48, 709-722.

Hosein, E.A., Pang, D., Tesfaye, Y. (1971). Some biochemical actions of carnitylcholine, a neuromuscular blocking agent. Biochem. Pharmacol., 20, 3385-3395.

Hosein, E.A., Proulx, P. (1964). Acetylcholine-like activity in subcellular particles isolated from rat brain. Arch. Biochem. Biophys., 106, 267-274.

Kalvinsh, I.., Gutcaits, A., Bagdoniene, L., Labeikyte, D., Trapencieris, P., Sjakste, N. (2006). Hypothetical gamma-butyrobetaine esterase-dependent signal transduction system: Possible link to mildronate action. Med. Hypotheses Res., 3, 803-812.

Laemmli, U.K. (1970). Cleavage of structural proteins during the assembly of the head of bacteriophage T4. Nature. 227, 680-685.

Lockridge, O., Schopfer, L.M., Winger, G., Woods, J.H. (2005). Large scale purification of butyrylcholinesterase from human plasma suitable for injection into monkeys; a potential new therapeutic for protection against cocaine and nerve agent toxicity. J. Med. Chem. Biol. Radiol. Def., 3, 1-23.

Morgan, E.W., Yan, B., Petersen, D. R., Greenway, D., Parkinson, A. (1994). Purification and characterization of two rat liver microsomal carboxylesterases (hydrolases A and B). Arch. Biochem. Biophys. 315, 495-512.
Nigg, H.N., Knaak, J.B. ( 2000). Blood cholinesterases as human biomarkers of organophosphorus pesticide exposure. Rev. Environ. Contam. Toxicol., 163, 29-111.

Orbidāne, O., Meirena, D., Pugovičs, O., Dzintare, M., Sjakste, J., Kalviņš, I., Sjakste, N. (2004). Gamma-butyrobetaine esterase activity in rat blood serum. Proc. Latv. Acad. Sci. B, 58, 98-102.

Sjakste, N., Kalvinsh, I. (2006). Mildronate: An antiischemic drug with multiple indications. Pharmacologyonline, 1, 1-18.

Sjakste, N., Gutcaits, A., Kalvinsh, I. (2005a). Mildronate: An antiischemic drug for neurological indications CNS Drug Reviews, 11, 151-168.

Sjakste, N., Sjakste, J., Boucher, J.L., Baumane, L., Sjakste, T., Dzintare, M., Meirena, D., Sharipova, J.s Kalvinsh, I. (2005b). Putative role of nitric oxide synthase isoforms in the changes of nitric oxide concentration in rat brain cortex and cerebellum following sevoflurane and isoflurane anaesthesia. Eur. J. Pharmacol, 513, 193-205.

Thomizek, W.D., Strack, E., Lorenz, J. (1963). Über den Einfluß einiger Derivate aliphatischen Trimethylbetaine auf die Acetylcholine-esterase und über die Hydrolyse von Betainestern. Acta Biol. Med. Germ., 11, 353-355.

Wheelock, C.E., Phillips, B.M., Anderson, B.S., Miller, J.L., Miller, M.J., Hammock, B.D. (2008). Applications of carboxylesterase activity in environmental monitoring and toxicity identification evaluations (TIEs). Rev Environ Contam Toxicol, 195, 117-178.

Абдикалиев Н.А., Калвиньш И.И., Меерсон Ф.3. (1991). Антиаритмическое действие синтетического аналога ацетилхолина на нарушения сердечного ритма, вызванные хлоридом кальция и строфантином. [The antiarrhythmic action of the synthetic acetylcholine analogue EDIHYP in calcium chloride- and strophanthin-induced heart rhythm disorders]. Фармакол. Токсикол., 54, 25-28 (in Russian).

Меерсон Ф.3, Абдикалиев Н.А., Калвиньш И.И., Вовк В.И. (1991а). Биоэлектрический механизм антиаритмического действия синтетического аналога ацетилхолина ЭДИГИП [Bioelectrical mechanism of the anti-arrhythmia effect of a synthetic acetylcholine analogue EDIHYP]. Кардиология, 31, 52-55 (in Russian).

Меерсон Ф.З, Калвиньш И.И., Абдикалиев Н.А. (1991b). Устранение нарушений электрической стабильности сердца и аритмии с помощью синтетического аналога ацетилхолина [Correction of disorders of electric stability of the heart and arrhythmia by using a synthetic analogue of acetylcholine]. Бюлл. Эксп. Биол. Мед., 111, 13-16 (in Russian).

Received 7 November 2008

\section{PROTOKOLS ŽURKU ASINS SERUMA PROTEĪNU GAMMA-BUTIROBETĪESTERĀZES AKTIVITĀTES BAGĀTINĀTAS FRAKCIJAS IEGŪŠANAI}

Neraugoties uz to, ka gamma-butirobetaīna esteri un tiem radniecīgi savienojumi jau sen ir pazīstami, tie nepiesaista pietiekošu pētnieku uzmanību, un šo savienojumu fizioloğiskās funkcijas paliek neizprastas. Iepriekš esam noteikuši gamma butirobetaīnesterāzes aktivitāti žurku asins serumā. Šì darba mērḳis bija izstrādāt pieeju, kas ḷautu attīīit individuālus žurku asins seruma proteīnus ar gammabutirobetaīnesterāzes aktivitāti. Hromatogrāfijā uz DEAE sefarozes pie pH4,2 izdevās iegūt ar fermenatīvu aktivitāti bagātinātu frakciju, kuras sastāvā bija daudzi polipeptīdi. Turpmāka šīs frakcijas hromatografija uz DEAE sefarozes pie pH 6,5 vai uz heparīna sefarozes pie pH 7,0 neḷāva samazināt polipeptīdu skaitu. Augstāk minēto frakciju sadalot, hromatografējot uz DEAE sefarozes pie pH 7,4 vai uz BioGel P150 GBB-esterāzes, aktivitāte zuda. Labākie rezultāti (68-kārtīga fermenta attīrǐšana) tika sasniegti, kombinējot hromatogrāfiju uz DEAE sefarozes pie $\mathrm{pH} 4,2$ ar afinitātes hromatogrāfiju uz prokainamīda. 